\title{
Integrated crop, nutrient and pest management for improving tomato, brinjal and chilli productivity in acid soils
}

\author{
A.K. SINGH
}

ICAR-Central Research Institute for Jute and Allied Fibres, Barrackpore, KOLKATA(W.B) INDIA

\section{ARITCLE INFO}

Received : 23.02 .2017

Revised : 13.03 .2017

Accepted : 18.03 .2017

\section{KEY WORDS :}

Integrated crop, Nutrient,

Pest management, Improving tomato, Brinjal, Chilli productivity, Acid soils

Email : singhak30@gmail.com

\begin{abstract}
Vegetable production is an important component of agriculture and also an essential part of a balanced human diet. In recent years, vegetable production has also become an income generating enterprise for those farmers who are located close to markets and road sides. Local varieties and practices are of low productivity, prone to pests and grown without proper fertilizer management resulting in poor yield and poor soil fertility. Modern technologies are often inappropriate for them due to lack of knowledge and training. However, a combination of traditional and appropriate modern technology like INM, IPM and improved variety can reap the good harvest of vegetables and support livelihood and nutritional security of farmers. Considering the importance of vegetable production and to meet the market demand of tomato, chilli and brinjal, onfarm research trials on INM and IPM system were conducted in acid soils of South Tripura (India).
\end{abstract}

How to view point the article : Singh, A.K. (2017). Integrated crop, nutrient and pest management for improving tomato, brinjal and chilli productivity in acid soils. Internat. J. Plant Protec., 10(1) : 106-110, DOI : 10.15740/HAS/IJPP/10.1/106-110. 